This article is licensed under the Creative Commons Attribution-NonCommercial 4.0 International License (CC BY-NC) (http://www.karger.com/Services/OpenAccessLicense). Usage and distribution for commercial purposes requires written permission.

\title{
Alpha-Fetoprotein-Producing Gastric Cancer with Nonbiliary Pancreatitis
}

\section{Arda Yavuz ${ }^{a} \quad$ Büşra Güleç ${ }^{b}$ Rabia Burçin Girgin ${ }^{c}$ İlyas Tuncer ${ }^{a}$}

${ }^{a}$ Gastroenterology Department, Göztepe Research and Training Hospital, Istanbul Medeniyet University, Istanbul, Turkey; ${ }^{b}$ Internal Medicine Department, Göztepe Research and Training Hospital, Istanbul Medeniyet University, Istanbul, Turkey; ${ }^{\text {CPathology }}$ Department, Göztepe Research and Training Hospital, Istanbul Medeniyet University, Istanbul, Turkey

\section{Keywords}

Pancreatitis · Alpha-fetoprotein · Metastasis · Gastric cancer

\section{Abstract}

Alpha-fetoprotein (AFP)-producing gastric cancer (AFPGC) is a rare, aggressive tumor. In the absence of metastasis in diagnosis, close observation and long-term follow-up is needed to monitor and slow its progress. We report a young patient who presented with nonbiliary pancreatitis. Upon finding Virchow's nodule, we conducted tests and observed multiple lymph nodes and liver and pancreatic metastasis. We subsequently made a diagnosis of AFPGC. This study describes the different presentations of this rare but aggressive subtype of gastric cancer with a review of the literature. 


\section{Case Reports in Gastroenterology}

\begin{tabular}{l|l}
\hline Case Rep Gastroenterol 2021;15:80-86 \\
\hline DOI: 10.1159/000511294 & $\begin{array}{l}\text { @ 2021 The Author(s). Published by S. Karger AG, Basel } \\
\text { www.karger.com/crg }\end{array}$ \\
\hline
\end{tabular}

Yavuz et al.: An Unexpected Cause of Pancreatitis

\section{Introduction}

Alpha-fetoprotein (AFP) is an oncogenic marker mainly produced by the yolk sac and fetal liver tissue, but also, to a lesser extent, in the fetal gastrointestinal tract [1,2]. AFP levels are highest between 12 and 15 weeks after birth and decrease to normal adult levels after 1 year. Higher AFP levels are also associated with hepatocellular carcinoma, yolk sac tumors, and noncancerous liver disease [3-6]. In some cancers, higher AFP levels can be detected in tumors of the stomach, lung, pancreas, colon, bladder, and ovary [7-13]. Bourreille et al. [14] reported the first AFP-producing gastric cancer (AFPGC) case in 1970. At present, we know that this subgroup of gastric tumors is highly aggressive.

Pancreatic metastases from malignancy are rare [15]. In autopsy series, the prevalence of pancreatic metastases ranges from 6 to 11\% [16]. Renal cell carcinoma is the most common cause of pancreatic metastasis, followed by non-small-cell lung cancer, colon cancer, and sarcomas [17].

Herein, we report a patient who was initially admitted for nonbiliary pancreatitis, the underlying cause of which was subsequently found to be gastric cancer.

\section{Case Report}

A 33-year-old Turkish male patient was admitted to the emergency services for severe stomachache. His pains had started 1.5 months previously. One week before admission, he was treated at another clinic for pancreatitis. In BT scan there was lymphadenopathy in the supraclavicular, mediastinal, and abdominal regions. The color of stool samples had become increasingly darker. He had weighted $70 \mathrm{~kg}$ before the disease and had lost 3-4 $\mathrm{kg}$ in the last 3 months, and had used three packs of flurbiprofen. He had no systemic disease, and his family history was unremarkable. He smoked cigarettes for 10 pack-years. He did not drink alcohol or use herbal medicine. On physical examination, he had Troisier's sign (palpable left supraclavicular lymphadenopathy). His pain partially decreased with hydration.

Abdominal ultrasonography showed that the gallbladder had sludge, seemed subhydropic, was $38 \mathrm{~mm}$ in diameter, and was $2.5 \mathrm{~mm}$ thick. Blood tests showed amylase at $332 \mathrm{U} / \mathrm{L}$ and lipase at $414 \mathrm{U} / \mathrm{L}$ (Table 1). We admitted the patient to evaluate further for malignancy and nonbiliary pancreatitis.

Gastroscopy revealed a 15-mm-wide gastric ulcer on the posteroinferior wall of the gastric corpus (Fig. 1). The surrounding mucosa was hypertrophic. We performed multiple biopsies. In contrast-enhanced BT, edema was extensive in the pancreatic head and corpus. Multiple lymphadenopathies were observed in the para-aortic and paraceliac nodes and portal hilus. These findings were compatible with pancreatitis. Moreover, we performed magnetic resonance cholangiopancreatography, which revealed multiple metastases in the liver. The pancreatic head presented a soft tissue density mass measuring $80 \times 60 \mathrm{~mm}$, which was probably associated with metastasis.

Positron emission tomography-computed tomography scans revealed lymph nodes and lesions in several areas. There were conglomerate lymph nodes (maximum standardized 


\section{Case Reports in Gastroenterology}

\begin{tabular}{l|l}
\hline Case Rep Gastroenterol 2021;15:80-86 \\
\hline DOI: 10.1159/000511294 & $\begin{array}{l}\text { @ 2021 The Author(s). Published by S. Karger AG, Basel } \\
\text { www.karger.com/crg }\end{array}$ \\
\hline
\end{tabular}

Yavuz et al.: An Unexpected Cause of Pancreatitis

uptake value $\left.\left[\mathrm{SUV}_{\max }\right]=13.0\right)$ in the left supraclavicular-lower jugular region. Multiple lymph nodes were found in the mediastinum, with the biggest one measuring $26 \mathrm{~mm}\left(\mathrm{SUV}_{\max }=16.7\right)$. In the liver, segment 4B had an 18-mm hypodense lesion and both lobes showed multiple lesions $\left(\mathrm{SUV}_{\max }=11.3\right)$. The antrum of the stomach had heterogeneous lesions $\left(\mathrm{SUV}_{\max }=13.3\right)$, while the pancreatic head and corpus had low-density lesions $\left(\mathrm{SUV}_{\max }=12.3\right)$. Multiple lymph nodes were also observed in the abdomen, particularly the periportal, retrocaval, para-aortic, and common iliac regions ( $\left.\mathrm{SUV}_{\max }=12.2\right)$ (Fig. 2).

Stomach pathology revealed widespread signet ring cell carcinoma (Fig. 3). Together with the high AFP levels obtained and other findings, the patient was diagnosed with AFP-producing nonhepatoid carcinoma, and we referred him to oncology and surgery. Biliary drainage was subsequently performed because of hyperbilirubinemia. He died after 1 month.

\section{Discussion}

Our patient was admitted to the hospital for nonbiliary pancreatitis, which did not present an immediate etiology. However, the finding of Virchow's nodule was revealing, leading us to uncover the underlying gastric cancer. Considering that AFPGC is an aggressive subtype of gastric cancer, the patient was already metastatic at diagnosis. Hydration decreased pancreatic pain and enzymatic action.

AFP-producing gastric tumors belong to an aggressive subtype of gastric cancer. Two different histological groups were identified by Nagai et al. [18] in 1993: AFP-producing nonhepatoid adenocarcinoma and hepatoid carcinoma. AFP gastric cancer has mostly only been diagnosed in the advanced stage. According to a 2014 study in Taiwan [19], the 1-, 3-, 5-, and 10-year survival rates of AFPGC patient with AFP levels of $20-300 \mathrm{ng} / \mathrm{mL}$ were $46.7,28.9$, 17.8 , and $13.3 \%$, respectively. In comparison, the survival rates of AFPGC patients with AFP levels $>300 \mathrm{ng} / \mathrm{mL}$ at $1-, 3-$, and 5-year follow-up were $15.4,7.7$, and $0 \%$, respectively. In that study, $2.2 \%$ had papillary adenocarcinoma, $41.3 \%$ had tubular adenocarcinoma, $43.5 \%$ had poorly differentiated adenocarcinoma, $6.5 \%$ had signet ring cell carcinoma, and $2.2 \%$ had adenosquamous carcinoma, while $2.2 \%$ were undifferentiated and $2.2 \%$ miscellaneous. The liver and lymph nodes were often involved.

Tumor stage, depth of invasion, degree of lymph node metastasis, AFP expression, and p21 expression are important predictors of prognosis [20]. Increased mitosis, cell movement, proliferative activity, tumor progression, hepatocyte and receptor growth factor, c-Met, VEGF, and VEGF-C isoform expression as well as the presence of p-glycoprotein are related to AFPGC and poor prognosis [21-24]. Hirashima et al. [25] reported AFPGC to be sensitive to cisplatin, but fluoropyrimidine prodrugs (e.g., capecitabine) are ineffective [26]. Due to the aggressiveness of AFPGC, early management and aggressive treatment options are important.

\section{Karger'=}




\section{Case Reports in Gastroenterology}

\begin{tabular}{l|l} 
DOI: 10.1159/000511294 & $\begin{array}{l}\text { (c) } 2021 \text { The Author(s). Published by S. Karger AG, Basel } \\
\text { www.karger.com/crg }\end{array}$
\end{tabular}

Yavuz et al.: An Unexpected Cause of Pancreatitis

\section{Statement of Ethics}

The research was conducted ethically in accordance with the World Medical Association Declaration of Helsinki. The authors wish to thank the family member who kindly gave written informed consent for this case to be presented in this report, including images.

\section{Conflict of Interest Statement}

The authors have no conflicts of interest to declare.

\section{Funding Sources}

The authors have no funding sources to declare.

\section{Author Contributions}

Dr. A. Yavuz wrote the manuscript and is the article guarantor. Dr. B. Güleç and Dr. R.B. Girgin revised the manuscript. Dr. İ. Tuncer revised the manuscript and approved the final version.

\section{References}

1 Gitlin D, Perricelli A, Gitlin GM. Synthesis of $\alpha$-fetoprotein by liver, yolk sac, and gastrointestinal tract of the human conceptus. Cancer Res. 1972 May;32(5):979-82.

2 Babalı A, Cakal E, Purnak T, Bıyıkoğlu I, Cakal B, Yüksel O, et al. Serum $\alpha$-fetoprotein levels in liver steatosis. Hepatol Int. 2009 Dec;3(4):551-5.

3 Mizejewski GJ. Levels of alpha-fetoprotein during pregnancy and early infancy in normal and disease states. Obstet Gynecol Surv. 2003 Dec;58(12):804-26.

4 Breborowicz J, Mackiewicz A, Breborowicz D. Microheterogeneity of alpha-fetoprotein in patient serum as demonstrated by lectin affino-electrophoresis. Scand J Immunol. 1981 Jul;14(1):15-20.

5 Ezaki T, Yukaya H, Ogawa Y, Chang YC, Nagasue N. Elevation of alpha-fetoprotein level without evidence of recurrence after hepatectomy for hepatocellular carcinoma. Cancer. 1988 May;61(9):1880-3.

6 Ganjei P, Nadji M, Albores-Saavedra J, Morales AR. Histologic markers in primary and metastatic tumors of the liver. Cancer. 1988 Nov;62(9):1994-8.

7 Yamagata T, Yamagata Y, Nakanishi M, Matsunaga K, Minakata Y, Ichinose M. A case of primary lung cancer producing alpha-fetoprotein. Can Respir J. 2004 Oct;11(7):504-6.

8 Hamanaka W, Yoneda S, Shirakusa T, Shirahama H, Tashiro Y, Iwasaki A, et al. Alpha-fetoprotein (AFP)producing adrenocortical carcinoma - long survival with various therapeutic strategies including a lung resection: report of a case. Surg Today. 2008;38(3):275-8.

9 Matsueda K, Yamamoto H, Yoshida Y, Notohara K. Hepatoid carcinoma of the pancreas producing protein induced by vitamin K absence or antagonist II (PIVKA-II) and alpha-fetoprotein (AFP). J Gastroenterol. 2006 Oct;41(10):1011-9.

10 Kinjo T, Taniguchi H, Kushima R, Sekine S, Oda I, Saka M, et al. Histologic and immunohistochemical analyses of $\alpha$-fetoprotein-producing cancer of the stomach. Am J Surg Pathol. 2012 Jan;36(1):56-65. 


\section{Case Reports in Gastroenterology} \begin{tabular}{l|l}
\hline DOI: $10.1159 / 000511294$ & $\begin{array}{l}\text { (c) } 2021 \text { The Author(s). Published by S. Karger AG, Basel } \\
\text { www.karger.com/crg }\end{array}$
\end{tabular}

Yavuz et al.: An Unexpected Cause of Pancreatitis

11 Cappetta A, Bergamo F, Mescoli C, Lonardi S, Rugge M, Zagonel V. Hepatoid adenocarcinoma of the colon: what should we target? Pathol Oncol Res. 2012 Jan;18(1):93-6.

12 Kawamura N, Hatano K, Kakuta Y, Takada T, Hara T, Yamaguchi S. A case of hepatoid adenocarcinoma of the urinary bladder. Hinyokika Kiyo. 2009 Oct;55(10):619-22. Japanese.

13 Isonishi S, Ogura A, Kiyokawa T, Suzuki M, Kunito S, Hirama M, et al. Alpha-fetoprotein (AFP)-producing ovarian tumor in an elderly woman. Int J Clin Oncol. 2009 Feb;14(1):70-3.

14 Bourreille J, Metayer P, Sauger F, Matray F, Fondimare A. Existence of alpha feto protein during gastricorigin secondary cancer of the liver. Presse Med. 1970 Jun;78(28):1277-8. French.

15 Hiotis SP, Klimstra DS, Conlon KC, Brennan MF. Results after pancreatic resection for metastatic lesions. Ann Surg Oncol. 2002 Aug;9(7):675-9.

16 Z'graggen K, Fernández-del Castillo C, Rattner DW, Sigala H, Warshaw AL. Metastases to the pancreas and their surgical extirpation. Arch Surg. 1998 Apr;133(4):413-7.

17 Robbins EG 2nd, Franceschi D, Barkin JS. Solitary metastatic tumors to the pancreas: a case report and review of the literature. Am J Gastroenterol. 1996 Nov;91(11):2414-7.

18 Nagai E, Ueyama T, Yao T, Tsuneyoshi M. Hepatoid adenocarcinoma of the stomach. A clinicopathologic and immunohistochemical analysis. Cancer. 1993 Sep;72(6):1827-35.

19 Lin HJ, Hsieh YH, Fang WL, Huang KH, Li AF. Clinical manifestations in patients with alpha-fetoproteinproducing gastric cancer. Curr Oncol. 2014 Jun;21(3):e394-9.

20 Liu X, Yu H, Cai H, Wang Y. Expression of CD24, p21, p53, and c-myc in alpha-fetoprotein-producing gastric cancer: correlation with clinicopathologic characteristics and survival. J Surg Oncol. 2014 Jun;109(8):85964.

21 Koide N, Nishio A, Igarashi J, Kajikawa S, Adachi W, Amano J. Alpha-fetoprotein-producing gastric cancer: histochemical analysis of cell proliferation, apoptosis, and angiogenesis. Am J Gastroenterol. 1999 Jun;94(6): 1658-63.

22 Amemiya H, Kono K, Mori Y, Takahashi A, Ichihara F, Iizuka H, et al. High frequency of c-Met expression in gastric cancers producing alpha-fetoprotein. Oncology. 2000 Aug;59(2):145-51.

23 Kamei S, Kono K, Amemiya H, Takahashi A, Sugai H, Ichihara F, et al. Evaluation of VEGF and VEGF-C expression in gastric cancer cells producing alpha-fetoprotein. J Gastroenterol. 2003;38(6):540-7.

24 Dhar DK, Nagasue N, Yoshimura H, Tachibana M, Tahara H, Matsuura H, et al. Overexpression of P-glycoprotein in untreated AFP-producing gastric carcinoma. J Surg Oncol. 1995 Sep;60(1):50-4.

25 Hirashima Y, Kitajima K, Sugi S, Kagawa K, Kumamoto T, Murakami K, et al. Successful bi-weekly paclitaxel treatment of an AFP-producing gastric cancer patient with peritoneal dissemination and multiple liver metastasis. Gan To Kagaku Ryoho. 2006 Apr;33(4):517-9. Japanese.

26 Kamoshida S, Suzuki M, Sakurai Y, Ochiai M, Kimura F, Kuwao S, et al. Expression of chemoresistance-related proteins in alpha-fetoprotein-producing adenocarcinoma of the digestive organs. Oncol Rep. 2006 Oct;16(4): $721-7$. 


\section{Case Reports in Gastroenterology}

Case Rep Gastroenterol 2021;15:80-86

(C) 2021 The Author(s). Published by S. Karger AG, Basel www.karger.com/crg

Yavuz et al.: An Unexpected Cause of Pancreatitis
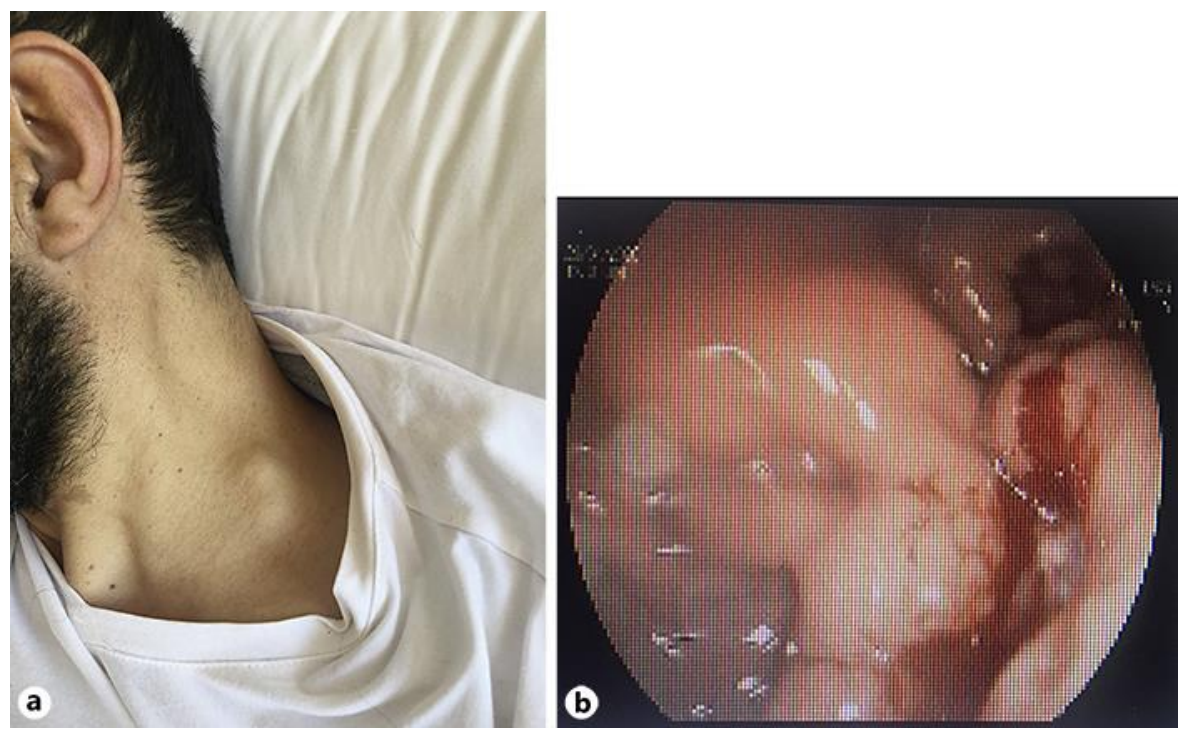

Fig. 1. a Virchow's nodule. b Malignant gastric ulcer in the gastric corpus.
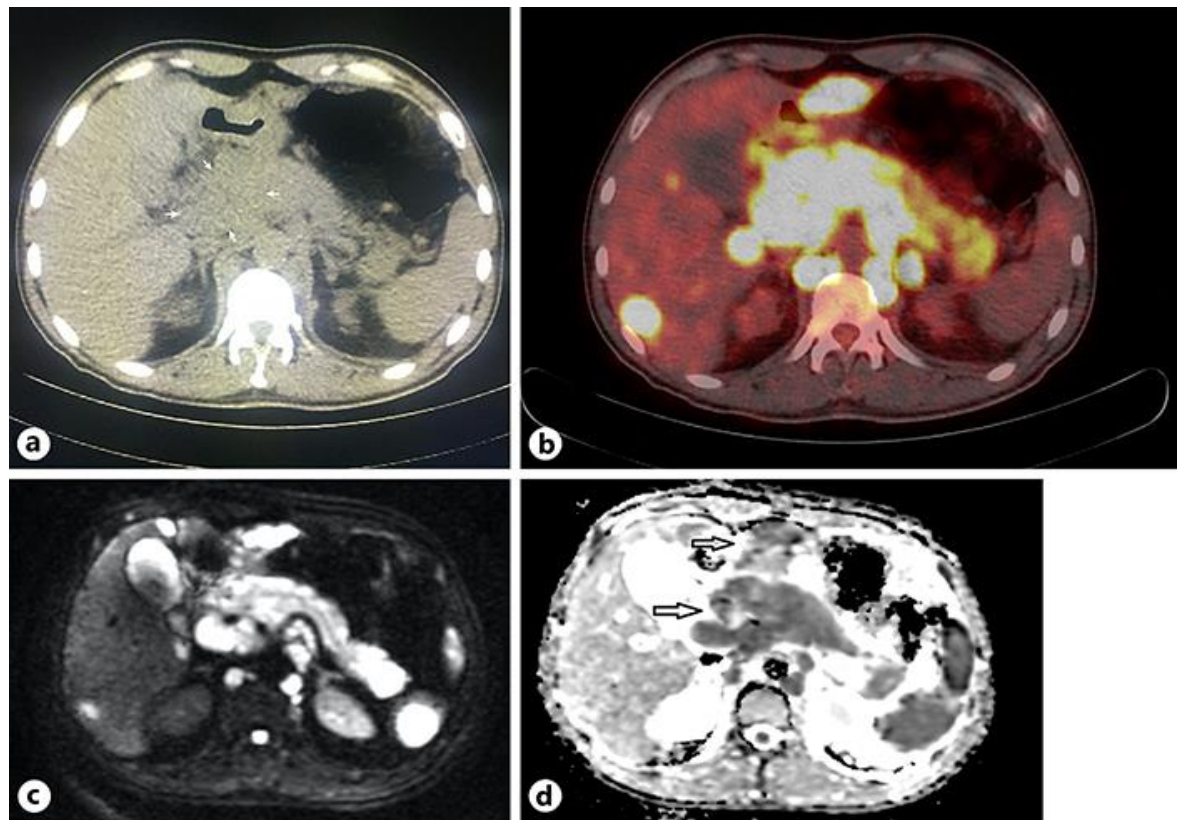

Fig. 2. Imaging of pancreatic metastasis. a Pancreatic metastasis in computed tomography. b Extensive involvement of the pancreatic head and corpus. c Pancreatic metastasis in magnetic resonance imaging. d Diffusion restriction in stomach tumor (upper arrow) and pancreatic metastasis (lower arrow). 


\section{Case Reports in Gastroenterology}

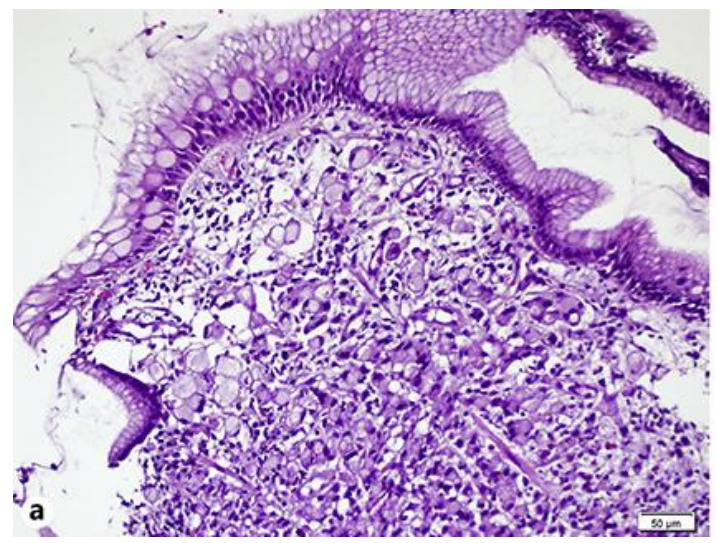

b

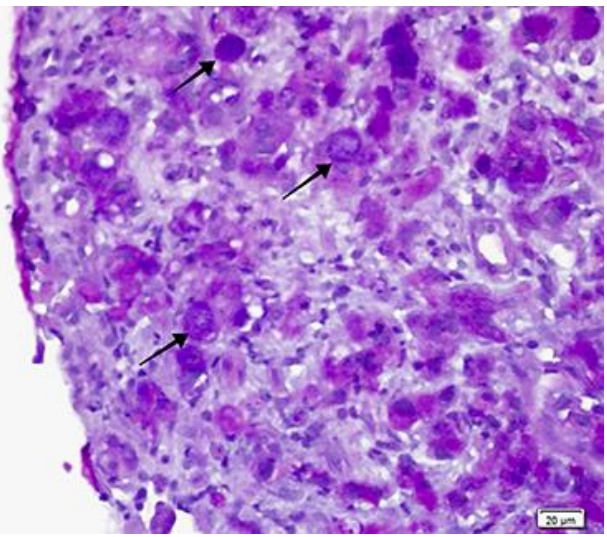

Fig. 3. Biopsy of the stomach corpus. a Widespread signet ring cell in the lamina propria $(\mathrm{H} \& \mathrm{E}, \times 200)$. b Intracellular mucin in signet ring cell (PAS-AB, ×400).

Table 1. Blood test results at hospital admission

\begin{tabular}{lll}
\hline Test & Normal value & $\begin{array}{l}\text { Hospital } \\
\text { admission }\end{array}$ \\
\hline AST & $0-37 \mathrm{U} / \mathrm{L}$ & 33 \\
ALT & $0-42 \mathrm{U} / \mathrm{L}$ & 20 \\
ALP & $40-150 \mathrm{U} / \mathrm{L}$ & 73 \\
GGT & $0-55 \mathrm{U} / \mathrm{L}$ & 54 \\
T.bil & $0-1.2 \mathrm{mg} / \mathrm{dL}$ & 0.36 \\
D.bil & $0-0.5 \mathrm{mg} / \mathrm{dL}$ & 0.14 \\
WBC & $4,000-10,000 / \mu \mathrm{L}$ & 6,900 \\
Hb & $13.5-17.0 \mathrm{~g} / \mathrm{dL}$ & 10.4 \\
MCV & $80-100 \mathrm{fL}$ & 90.9 \\
Amylase & $0-125 \mathrm{U} / \mathrm{L}$ & 332 \\
Lipase & $<78 \mathrm{U} / \mathrm{L}$ & 414 \\
AFP & $<9 \mathrm{ng} / \mathrm{mL}$ & 191.63 \\
CA125 & $<35 \mathrm{U} / \mathrm{mL}$ & 21.4 \\
CA19-9 & $<37 \mathrm{U} / \mathrm{mL}$ & 35.41 \\
CA15-3 & $<30 \mathrm{U} / \mathrm{mL}$ & 9.6 \\
Triglycerides & $<150 \mathrm{mg} / \mathrm{dL}$ & 104 \\
\hline
\end{tabular}

\section{Karger'=}

